\title{
39. Kurmacada trajik hatanın işlevi ve dramatik bir hikâye
}

\section{Gülsemin HAZER ${ }^{1}$}

APA: Hazer, G. (2021). Kurmacada trajik hatanın ișlevi ve dramatik bir hikâye. RumeliDE Dil ve Edebiyat Araşturmaları Dergisi, (24), 690-705. DOI: 10.29000/rumelide.997566.

\section{$\ddot{\mathbf{O} z}$}

Kurmaca eserler, farklı hikâyeler anlatarak insanın kendini ve yaşadı̆̆ı hayatı, anlayıp anlamlandırmasına yardımcı olurlar. Anlatının bu işlevini yerine getirmesinde ona destek olan disiplinlerden biri de psikolojidir. Yazara, farklı kimlik ve kişiliklerde karakterler üretme ya da kurmaca kişiler için sorun, sıkıntı, hastalık oluşturmada veriler sunan psikolojinin, bu anlamda işlevsel bir rol üstlendiği söylenebilir. Edebî eserde yer alan kurmaca öznenin psikolojisinin oluşturulması çok yönlü bir süreçtir. Bir yandan temel kişilik özellikleri belirlenirken bir yandan da bu kişiliğin gelişmesine neden olan olay, olgu ve durumların belirlenip kurguya yerleştirilmesi gerekir. Hikâyelerinde genellikle incinmiş ya da incitilmiş, mutsuz, yalnız kahramanların kederli hayatlarını anlatan Ayfer Tunç, kaderin trajik, dramatik ya da acı tarafıyla ilgilenmeyi seçmiş bir yazardır. Tunç, hikâyelerinde, sadece mutsuz hayatlardan sahneler sunmaz, aynı zamanda mutsuzluklar içinde yaşayan bireylerin varoluş biçimleriyle de ilgilenir. Dolayısıyla hikâyelerinde kurmaca kişilerin psikolojilerini anlamayı kolaylaştıracak olay, durum ve olguları da ortaya koyar. Bu nedenle onun hikâyeleri çözümlenirken dramatik aksiyonu oluşturan olaylarla ilgilenildiği kadar, olaylar dizisinin merkezinde yer alan kahramanın kurgulanma biçimiyle de ilgilenmek gerekir. Psikoloji biliminin verileri ise, bu trajik benliklerin anlaşılmasını kolaylaştıracaktır. Bu makalede, kökeni mitlere dayanan "trajik hata" ve onunla ilişkili olarak gelişebilen "aşă̆llık kompleksi”nin kurmaca kişi oluşturmadaki işlevi üzerinde durulmuş ve bunların trajik yapıyla ilgisi gösterilmiştir. Trajik hata ile bağlantılı olduğunda, başka sorun ve hastalıklara da neden olan aşağılık kompleksinin, kurmaca kişi ve kurmaca kader üzerindeki etkisi ise Ayfer Tunç’un “Aziz Bey Hadisesi” adlı hikâyesi üzerinden gösterilmeye çalışılmıştır.

Anahtar kelimeler: “Aziz Bey Hadisesi”, Peter Pan sendromu, narsisizm, aşağılık kompleksi, trajik hata

\section{The function of tragic errors in fiction and a dramatic story}

\begin{abstract}
Fiction works help people to understand and make sense of themselves and the life they live by telling different stories. One of the disciplines that supports the narrative in fulfilling this function is psychology. It can be uttered that psychology, which provides data for the author to produce characters with different identities and personalities, or to create problems, distress and disease for fictional people, plays a functional role in this sense. The creation of the psychology of the fictional subject in the literary work is a multi-faceted process. While determining the basic personality traits, the events, facts and situations causing the development of this personality should be determined and placed in the fiction. Ayfer Tunç, who usually tells the sad lives of hurt or aggrieved, unhappy, lonely heroes in her stories, is a writer who chose to deal with the tragic, dramatic or painful side of fate. In
\end{abstract}

Doç. Dr., Sakarya Üniversitesi, Fen Edebiyat Fakültesi, Yeni Türk Edebiyatı Bölümü, Türk Dili ve Edebiyatı (Sakarya, Türkiye), ghazer@sakarya.edu.tr, ORCID ID: oooo-0oo1-7784-4429 [Araştırma makalesi, Makale kayıt tarihi: 25.08.2021-kabul tarihi: 20.09.2021; DOI: 10.29000/rumelide.997566]

Adres | Address

RumeliDE Dil ve Edebiyat Araştırmaları Dergisi Osmanağa Mahallesi, Mürver Ciçeği Sokak, No:14/8 Kadıköy - İSTANBUL / TÜRKIYE 34714 e-posta: editor@rumelide.com

RumeliDE Journal of Language and Literature Studies Osmanağa Mahallesi, Mürver Çiçeği Sokak, No:14/8

Kadıköy - ISTANBUL / TURKEY 34714 tel: +90 505 7958124, +90 2167730616

e-mail: editor@rumelide.com,

phone: +90 5057958124 , +90 2167730616 


\begin{abstract}
her stories, Tunç not only presents scenes from unhappy lives, but also deals with the existence of individuals living in unhappiness. Therefore, she also reveals events, situations and facts that will make it easier to understand the psychology of fictional people in her stories. For this reason, it is necessary to deal with the fictional style of the hero being at the center of the storyline, as much as the events that make up the dramatic action while analyzing her stories. The data of the science of psychology will make it easier to understand these tragic selves. In this study, the role of "tragic error", which is based on myths, and the "inferiority complex" that can develop in relation to it, is emphasized regarding creation of fictional characters, and their relation to the tragic structure is indicated. The effect of the inferiority complex, which causes other problems and diseases when connected with the tragic mistake, on the fictional person and the fictional destiny has been tried to be shown through Ayfer Tunç's story "The Aziz Bey Incident (Aziz Bey Hadisesi)".
\end{abstract}

Keywords: "The Aziz Bey Incident”, Peter Pan syndrome, narcissism, inferiority complex, tragic error

\title{
Giriş
}

Kurmaca metinlerin temel unsurlarından biri kurmaca kişi(ler)dir. Çoğu anlatı, kurmaca kişinin etrafında gelişen olaylara ya da o kişinin eylem ve etkinliğine bağlı olarak gelişir. Bu tür yapılarda dramatik aksiyon genellikle bir kişi üzerine kurulur ve olaylar onun etrafında şekillenir. Böyle bir tercih, anlatının diğer unsurlarını da kurmaca kişiye çizilen kadere göre kurgulama zorunluluğunu doğurur. Kurmaca kişiye kader tayin etmek ise, çok boyutlu bir süreçtir ve esin kaynaklarına göre değişiklikler arz eder. Yazar, dilerse kahramanını dış dünyanın gerçekliğinden hareketle kurgular ya da tamamen bir hayal ürünü olarak tasarlayabilir. Şüphesiz ikisini mezcetme şansı da vardır. Ancak kurmaca kişinin etkileyici tarafını, ona giydirilen kişiliği oluşturur. Bu kişiliğin psikolojik boyutunu yaratma aşamasına gelindiğinde, yazarın karşısına geniş bir seçenekler dünyası çıkar. Kahraman, psikolojik açıdan bakıldığında kıskanç, bencil, diğerkâm, korkak, cesur, kibirli, merdümgiriz veya heyecanlı bir kişidir. Bu kişilik özelliklerinin oluşumuna neden olan olgu ve durumlar ancak psikoloji biliminin ışı̆̆ında aydınlatılabilir. Yazarın, söz konusu edilen bu ikinci kısmı derinlemesine işlemiş olması, kahramanını etkileyici bir kişiliğe büründürür. Bu tür kahramanlar, "edebî eserlerde görülen psikolojik tiplerin ve kanunların incelenmesi”(Wellek ve Warren, 1993: 62) bakımından da kıymetlidir. Yazar, kahramanındaki belirgin psikolojik durumu oluştururken; Oedipus karmaşasından, nevrotik bir çatışmadan, bir kimlik krizinden, arketiplerden, aşağllık kompleksi ve kardeş rekabetinden ya da varoluşsal çatışmalardan ${ }^{2}$ yararlanmış olabilir. Bu durumda kahramanın kişiliğini ve kaderini anlayabilmek adına sırasıyla; psikanalize, gelişim psikolojisine, analitik psikolojiye, bireysel psikolojiye ve son olarak varoluşçu ya da hümanistik psikolojiye müracaat etmek gerekir. Öte yandan bu başlıklar sadece ana alanlara işaret ederler. Kahramanın psikolojisini ya da psikoloji ile kader ilişkisini çözmek üzere bu alanlardan birine gidildiğinde, meselenin ne kadar karmaşık olduğu görülecektir.

Bu çalışmada "trajik hata" ve "aşağılık kompleksi”"nden hareketle kurmaca kişi(ler) oluşturma ve trajik bir yapı var etme üzerinde durulmaya çalışılacak ve buna iyi bir örnek olduğu düşünülen Ayfer Tunç’un “Aziz Bey Hadisesi” adlı hikâyesi çözümlenmeye gayret edilecektir.

William Indick, Senaryo Yazarları İçin Psikoloji (2011) adlı kitabında kurmaca karakterleri, yukarıda verilen kuram ve yaklaşımlar doğrultusunda değerlendirmiştir.

Adres

RumeliDE Dil ve Edebiyat Araştırmalar Dergisi Osmanağa Mahallesi, Mürver Ciçeği Sokak, No:14/8 Kadıköy - İSTANBUL / TÜRKIYE 34714 e-posta: editor@rumelide.com tel: +90 505 7958124, +90 216773 o 616

\section{Address}

RumeliDE Journal of Language and Literature Studies

Osmanağa Mahallesi, Mürver Çiçeği Sokak, No:14/8

Kadıköy - ISTANBUL / TURKEY 34714

e-mail: editor@rumelide.com,

phone: +90 $5057958124,+902167730616$ 


\title{
1. Trajik hata ve aşağılık kompleksi
}

Trajik hata/kusur (hamartia)3, kahramanın kusurlu tarafına işaret etmektedir. Özdemir Nutku, Dram Sanatında "trajik kahramanın yaptığı bir hatayla bahtında bir dönüşüm olmasıyla ortaya çıkan trajik durum hamartia'dır" (1990: 48) diyerek kahramanın bir hatasının ya da kusurunun trajediyi hazırladığına işaret eder. Sevda Şener de tragedyalar üzerinden trajik hatayı ve bunun kişi var etme üzerindeki rolünü şöyle açıklar:

\begin{abstract}
"Trajik Hata (Hamartia): Tragedya kahramanının seyircide istenen etkiyi yaratabilmesi, aynı zamanda seyircinin ahlak duygusuna ters düşmemesi için belli koşullara uyması gerekir. Eğer tragedyanın kaçınılmaz gelişimi içinde, mutluluktan yıkıma sürüklenen kişi çok erdemli ise, böyle erdemli bir kişinin yıkımı, seyircide korku ve acıma değil, öfke uyandırır. Öte yandan kötü bir kişinin yıkımı da seyirciyi çok etkilemez. Seyirci bunu doğal karşılar ve hakkın yerine geldiğini düşünür. Tersine, eğer kötü bir kişi mutluluğa erişirse, bu durum seyircinin adalet duygusunu çok incitir ve trajik etki yaratmaz. Onun için tragedyada karakterin ne çok iyi, ne çok kötü olmaması, bu iki tipin ortasında bulunması en iyi yoldur. Böyle bir kişi, iyi olmasına karşın, 'ne ahlak yetisi, ne adalet bakımından olağanüstü' değildir. Ahlak bakımından düşük ve kötü de olmaması gerekir. Bu, ortalamadan daha iyi olan karakterin bir hatası olmalıdır. Bu hata (hamartia), iyi bir insanın, bilmeden yaptığı yanlış hareket, ya da ahlaki olmayan bir zayıflıktır ve kişi bu hatası yüzünden yıkıma uğrar. İşte, iyi bir kişinin bilmeden yaptığı bir hareket yüzünden, ya da küçük bir zaafa kapıldığı için yıkıma uğraması, seyircide korku ve acıma duyguları uyandırır ve istenen trajik etki elde edilmiş olur." (2006:37-38)
\end{abstract}

Şener'in tragedyalardan hareketle tiyatro kişileri için belirlediği bu tespitin, roman ve hikâye için de geçerli olduğu söylenebilir. Zira kusursuz bir kişilik yerine, okurda sempati uyandıracak kadar iyi, ama zaaflarını, kusurlarını görmemekte ısrar eden bir kahramanın trajedisi, ciddi bir etki uyandıracaktır. Kahramanın kaderinde önemli bir rol oynayan bu kusurun, onun aklı ya da iradesi dışında gerçekleşmiş olması ise, trajik etkiyi artıran en önemli taraftır.

William Indick, Senaryo Yazarları İçin Psikoloji (2011) adlı kitabında "mitsel yapıda kahramanın karakterinin ortak bir ögesinin, kahramanın üstesinden gelmek zorunda olduğu trajik kusuru (hamartia) olduğunu belirtir ve klasik kahramanlar arasındaki en yaygın trajik kusurun, başlarını belaya sokacak olan aşırı gurur (hubris), kendini beğenmişlik ve kibir duygusu olduğunu söyler." (2011:214) Kurmaca kişinin mizacını belirleyen gurur, inatçılık, öfke, kendini beğenmişlik gibi duygular, anlatıda çoklu bir işlev üstlenirler. Bu tür bir huy, bir yandan kurgusal "ben”i ya da kurmaca kişiyi oluştururken bir yandan da dramatik aksiyonu yönlendirebilir. Poetika'da öykünün ögeleri olarak gösterilen baht dönüşü (peripetie) ve tanınma (anagnorisis) ile kahramanın trajedisi arasında bir ilişki olduğu gösterilmiştir. (Aristoteles, 1987: 15-19) Nutku, “[t]rajik kahramanın alın yazısında ortaya çıan bir dönüşümü anlatan peripetie kavramının hamartia’yaya sıkı sıkıya bağlı” olduğunu belirtir ve “Peripeti’nin, bir oyundaki iki farklı görünüşüyle aksiyonu karmaşı bir duruma getirdiğine” (1990: 4950) işaret eder. Nutku, hamartia ile ilişkili olan anagnorisis (bilgisizlikten bilgiye geçiş) kavramını ve bunun trajik durumla ilişkisini ise Oidipus üzerinden şöyle açıklar:

"Bu kavramın hamartia ile de ilgisi vardır. Oidipus, evli olduğu kadının (Lokaste’nin) öz annesi olduğunu anladığı nokta anagnorisis'tir. Oidipus o andan itibaren işlediği bir suçun bilincinde olarak trajik bir durumun (hamartia) içine düşer. Burası aynı zamanda peripeti, yani kahramanın bahtının dönüştüğü noktadır. Oidipus, yolda bilmeden öldürdüğü kişinin de öz babası olduğunu öğrenir. Böylece, anagnorisis yoluyla hamartia'ya gidilir. Ayrıca, baht dönüşümü de trajik durumu yarattığına göre, bu üç kavram (anagnorisis-peripeti-hamartia) birlikte düşünülmelidir. Bunlar trajik kahramanı ve trajik durumu ortaya çıkaran üç temel öğedir.” (1990: 50)

“Trajik kusur (hamartia), Achilles’in Topuğu, Achilles’in trajik kusuruna, yaralanmasın diye annesi tarafindan mitsel nehir Styx’e daldırıldığında sadece topuğu dışarıda kaldığı için bedeninin tek yaralanabilir kısmına gönderme yapar.” (Indick, 2011: 214) 
Buradan hareketle kahramanın trajedisinin, genellikle kendi iradesi dışında vuku bulan kırılma anlarından birinde gerçekleştiği ve bunda trajik hatanın da payı olduğu söylenebilir. Trajik hata, roman ve hikâyede de benzer bir yapı ortaya çıkarır. Anlatının evrelerinden olan dönüştürücü öge veya bitiş durumunda (Kıran ve Kıran, 2003: 21-22) kahraman açısından kadersel bir kırılma yaşanabilir ve buna neden olan durumlardan biri de trajik hatadır. Şüphesiz mitsel anlatılardan bugüne, kahramanın hikâyesi değişime uğradığı için trajik hatanın metindeki görünümü de farklılaşmıştır.

Trajik hataya sahip bir kahraman üzerine kurulu olan anlatılar, genelde trajik bir yapı sergiler. Zira trajik yapılı kurmaca metinlerin bazılarında okurun "sempati duyduğu bir kişinin, kendisini değiştirebilme güç ve potansiyeline sahip olduğu halde, uğradığı talihsizlik, verdiği yanlış bir karar ya da bir hatadan dolayı trajik bir durum ortaya çıkarken, bazılarında trajik duruma kahramanın kusurlu ve kibirli tabiatı neden olur." (Stevick, 2004: 142-143) Kurmaca kişinin sahip olduğu trajik hata, anlatılarda bir tür yüceltmeye ya da olumlamaya aracılık edebilir. Eğer, kahramanın kendisini adadığı büyük bir ideal varsa, bu durumda trajik hata, tematik bağlamda bir işlev üstlenmiş demektir. Bu yapının, çoğu kahramanlık hikâyesinde kullanıldığı görülür. Trajik hata, aşağılık kompleksiyle ilişkilendirildiğinde ise, psikolojik açıdan daha girift bir durum ortaya çıkar. Modern anlatılarda, anlatı kişisi adına gündeme gelen bu karmaşık durum, "trajik bir benlik" üretmenin de anahtarını verir. Indick'in "trajik kusur, aşağıllk kompleksinin, kahramanın üstesinden gelmek zorunda olduğu temel zayıflı̆̆ın, kusurun ya da zaafın kökenidir" (2011: 214) tespiti, bu iki unsur arasındaki ilişkinin öncelik sonralık durumuna işaret etmektedir. Trajik hatanın aşağıllı kompleksiyle ilişkilendirilmesi hem kurmaca kişinin psikolojisini anlamayı kolaylaştırır hem de olgunun daha gerçekçi bir zemine oturmasını sağlar. Aksi halde kibir, gurur ya da kendini beğenmişlik gibi bir huy nedeniyle felakete uğrayan kişinin, durumunu anlamak güçleşir. Trajedi yaratan huy ya da karakter özelliğinin neden ve nasıl doğduğunu veren aşağılık kompleksidir.

Anlatıda kimlik kazanan öznenin, dramatik aksiyonun sonunda "trajik bir benliğe" dönüşmüş olması, kendini kurma sürecindeki yaklaşımıyla ilişkilidir. Bu yönüyle "kurgusal bir benlik" oluşturan kurmaca kişinin, bilinç ve psikolojisinin gelişiminde ailesiyle ya da yetişkinlerle kurduğu ilişki gözden geçirilmelidir. Yazara, bireysel psikolojiden yararlanarak "trajik bir benlik" yaratma yolunda yardımcı olan aşağılık kompleksinin beraberinde getirdiği saygınlık çabası (Adler, 2009: 93) ise, dramatik aksiyonda entrik bir yapının doğmasına yardımcı olur. Bu noktada belirtilmelidir ki, "her ruhsal yaşamın başında az çok yer alan aşağllık duygusu", kurmaca kişi söz konusu olduğunda "itici bir güç oluşturarak" (Adler, 2009: 93) onu salim bir yola sevk etmeyebilir. Yani kurmaca kişinin "normalden daha güçlü, daha yoğun ve daha uzun süreli [yaşadı̆̆ı] aşağıllı duygusu[nu]" (Adler, 2009: 93) dengelemesi beklenen saygınlık ve üstünlük çabası, "aşırı dengelenmeye doğru evrilir” ve kurgusal kişilikte "patolojik ve uyumsuz davranışlara ve bir üstünlük kompleksine” (Indick, 2011: 215) dönüşür. Bu tür patolojik bir durum, trajedi yaratmak için uygun zemini de hazırlamış olur.

Adler'in, yetişkinlerin çocuğa yönelik yanlış tutum ve davranışlarının sebep olduğunu söylediği aşağıllk kompleksi, karmaşık bir durumdur. Adler'e göre çocuğun yetişkinlere göre yetersiz, güçsüz ve zayıf olduğu çocukluk döneminde, onu eğitirken, aşağılamak, beceriksizlikle suçlamak ya da yapabilirliğini aşan bir görev vermek aşağılık kompleksini doğuracaktır. (2009: 94-95) Aşağılık kompleksi aslında aşılabilir bir sorun gibi görünmektedir. Ancak bu noktada çocuğun bu duyguyu aşmak için gösterdiği çaba să̆lıksız bir yola evrilirse, başka bir sorun olan “üstünlük kompleksi” ortaya çlkar. Adler, bu süreci söyle açıklar:

"Aşağılık, güvensizlik ve yetersizlik duyguları yaşamda bir amacın saptanmasını ve biçimlendirilmesini sağlar. Daha yaşamının ilk günlerinde ön plana çıkmak, anne ve babasının

Adres | Address

RumeliDE Dil ve Edebiyat Araşttrmaları Dergisi $\quad$ RumeliDE Journal of Language and Literature Studies Osmanağa Mahallesi, Mürver Çiçeği Sokak, No:14/8 Osmanağa Mahallesi, Mürver Çiçeği Sokak, No:14/8 Kadıköy - İSTANBUL / TÜRKIYE 34714 Kadıköy - ISTANBUL / TURKEY 34714 e-posta: editor@rumelide.com e-mail: editor@rumelide.com, tel: +90 505 7958124, +90 2167730616 phone: +90 505 7958124, +90 2167730616 


\begin{abstract}
dikkatini üzerine çekmek, onları buna zorlamak özelliği kendini açığa vurur çocukta. Bu tür davranışlar insandaki saygınlığa kavuşma eğiliminin ilk belirtileridir, aşağılık duygusunun etkisiyle oluşur ve çocuğu çevresine karşı bir üstünlük duygusuyla donatacak bir amaç saptamaya iter. (...) $\mathrm{Ne}$ var ki, aşağılık duygusu çok güçlüyse, çocuğun ileride pek istediği gibi yaşayamayacağından korkarak normal bir dengelemeyle [kompensasyon] yetinmeyip, işi daha ileriye götürme ve aşırı ölçüde bir dengelemeye başvurma tehlikesi ortaya çıkabilir. Güçlülük ve üstünlük eğilimi oldukça aşırılığa vardırılarak hastalık derecesinde bir düzeye çıkarılır. Bu gibi çocuklar, yaşamlarındaki normal ilişkilerle yetinmez, çok yüksekte saptadıkları amaçlara uygun olarak dikkati çeken büyük eylemlere girişir. (...) En başta kendini beğenmişlik, büyüklenme, her ne pahasına olursa olsun başkalarını egemenlik altına alma, ilgili özellikler arasında yer alır. (...) Ne var ki, yaşam karşısında takınılan böyle bir tutum yalnızca çevreyi rahatsız etmekle kalmaz, ilgili tutumun sahipleri için de birtakım tatsız sonuçlar doğurur. Onları hayatın gölge taraflarıyla öylesine donatır ki, bu kişiler yaşamın doğru dürüst tadına varamazlar." (2009: 96-101)
\end{abstract}

Bu açıklama aşağılık kompleksinin ne kadar karmaşık bir sorun olduğunu gösterdiği gibi, başka rahatsızlıklara neden olduğunu da işaret etmektedir.

Kurmacada hem yapısal ögelerle hem de içerik ögeleriyle ilişkili olan kurmaca kişiler, dramatik aksiyon içindeki entrik yapıda da etkin bir rol üstlenirler. Bu nedenle yazar, kurmaca benlikleri üretirken bütün bu unsurları göz önüne alarak hareket eder. Eğer, trajik bir öykü oluşturmaya çalışıyorsa, yaratıcılığını trajik bir kahraman oluşturma yönünde kullanacaktır. Bu bağlamda trajik hatadan ve aşağllık kompleksinden yararlanmanın, kurmaca kişinin "benlik" inşasında elverişli bir alan açtığını söylemek yanlış olmayacaktır. Hatta birbiri ile bağlantılı olan trajik hata ile aşağılık kompleksi, başka kişilik problemleri ya da sorunlarına da kapı aralayabileceği için, kurmaca kişinin trajedisinin derece ve niteliğini de belirleyecektir. Böylece bireysel psikolojinin alanına giren bir sorun, kurmaca kişi adına kırgınlık, hüzün, dram ya da trajedi üretmek için kullanılmış olur. Üstelik kurmaca kişinin benlik ve kimliğinin oluşumunda başka kişilerin tavır, davranış ve tutumları da etkili olduğundan, diğer kişilerin tasarımında da değişik ölçülerde psikolojiden yararlanılır. Bu durum sadece kurmaca kişileri belirlemez, aynı zamanda dramatik aksiyonda entrik yapıyı hazırlayacak olan karmaşık ilişkiler ağını da oluşturur.

Kurmaca kişiler için tespit edilmesi gereken bir diğer husus, tip ya da karakter olarak tasarlanmaları durumudur. Trajik hata ile aşağılık kompleksinden yararlanılmış olması, kurmaca kişilerin tip ya da karakter olarak tanımlanmalarında etkilidir. Bu noktada denilebilir ki, trajik hataya sahip olan kurmaca bir kişi, daha çok tip olma vasfi taşırken, aşağılık kompleksiyle buluşmuş bir trajik hata, kurgulanan kişiyi rahatlıkla bir karaktere dönüştürebilir. Karakter üretiminde yazarın yaratıcı bilinci, psikolojiden ne kadar yararlanırsa, ürettiği kurgusal kahraman o ölçüde karmaşık bir kişiliğe sahip olur. Indick, üstünlük kompleksi olan birinin (genellikle kötü) karakter olarak tasarlandığını, ancak kötü karakterin aşırı dengeleme davranışının ardındaki aşağılık kompleksini açığa vuracak şekilde tasarlanmasının, onu tek boyutlu bir kişi olmaktan çıkardığını belirtir. (2011: 215) Konuyla ilgili açıklamasında önemli bir noktanın daha üzerinde durur. "Bu başarıldığında kötü, tek boyutlu bir karakter işlevi görmeyecektir. İzleyici kötü karakterin neden kötü olduğunu anlayacak ve karakterinden nefret ettiği kadar ona acıyacaktır" diyen Indick'e göre;

Süper kötü aşırı dengelemenin ve üstünlük kompleksinin aşırı bir örneğiyken, bu dürtüler ve çatışmalar bütün karakterlerdeki ortak motivasyonlardır. Bunlar kahramanlarda (özellikle trajik kahramanlarda), rakiplerde, destekleyici, hatta yol gösterici karakterlerde karakter motivasyonlarının etkili araçları olabilirler. Örneğin bir oyuncu olarak başarısız kariyerini dengelemek için takımını psikotik bir zafer gereksinimiyle zorlayan basketbol koçu, yol gösterici karakterdeki üstünlük kompleksinin arketipik bir örneğidir. (2011: 217)

Yukardaki açıklamanın da işaret ettiği gibi aşağılık kompleksinin aşırı dengelenmesinin ortaya çıkardığı üstünlük kompleksi, sadece kötü tipler için söz konusu değildir. Kurmaca evrenin merkezinde yer alan 
ve tam olarak "kötü" sıfatını hak etmeyen çoğu kurgusal kimlik ya da kurmaca kişi böyle tasarlanmış olabilir. Üstelik bu durum, yukarıda ifade edilmeye çalışıldığı gibi karakter tasarımında yazarın işine yaramaktadır. Çünkü kahraman açısından sorunlu benlik oluşturan tek unsur; çocukluk dönemi, mizaç, aile ve diğer yetişkinlerle olan ilişki değildir. Trajik hata veya kusur, aşağılık kompleksiyle buluştuğunda daha karmaşı kişilik sorunlarını ortaya çıkarabilir. Bu karmaşı yapı, sendrom olarak nitelenen rahatsızlıklardan başlatılarak bir kimlik krizine kadar genişletilebilir. Bir diğer ifadeyle trajik hata ile buluşan aşağllık kompleksi ve bunun ortaya çıkardığı üstünlük kompleksi, gerçekte olduğu gibi kurgusal metinlerde de kurmaca kişilerin başka rahatsızlık, sorun ve hastalıklarla uğraşmasına neden olabilir. Bu çalışmada çözümlenmeye çalışllacak olan Ayfer Tunç’un “Aziz Bey Hadisesi” hikâyesinde, başkişinin kurgusal kişiliğinde var olduğu görülen trajik hata -ki kahraman adına bunu daha çok kusur olarak görmek mümkündür- aşağılık kompleksiyle buluşmuş ve üstünlük kompleksine dönüşmüştür. Öznenin trajik kaderinde, bir de üstünlük kompleksinin tetiklediği "Peter Pan Sendromu” ortaya çıkar. Bütün bu sorunlar, kahramanın genetik olarak taşıdığı tavır, davranış ve tutumlarla birleşince, kurmaca kişi için dramatik bir kader doğmuş olur. Bu bağlamda acı ve trajik olanı hazırlayan bütün unsurlar birlikte düşünülmedikçe bu kader hikâyesinin kahramanını çözmek zor olacaktır.

“Aziz Bey Hadisesi” hikâyesinin çözümünde söz konusu edilecek olan "Peter Pan Sendromu” Dr. Dan Kiley tarafından psikoloji literatürüne kazandırılmış bir rahatsızlıktır. Dan Kiley, bunun insan yaşamını tehdit etmediğini, bu yüzden bir hastalık olarak değerlendirilmediğini ama psikolojik bir olgu olduğunu belirtir. Kiley, insan hayatında birçok probleme neden olan bu sendromun, akıl sağlı̆̆ını tehdit ettiğini belirterek basit bir rahatsızlık olarak görülmemesini ister. Kiley'e göre, "bu yeni bir psikolojik olgudur. Bilinen herhangi bir kategoriye girmez, ama varlığı da inkâr edilemez. (...) Parlak, duyarlı bir çocuğun, olgunlaşmamış, öfkeli bir yetişkin haline gelmesinde" (1997: XV-XVI) suçlanan anne ve babaların yanlış tutum ve davranışları, erkek çocuklarında ciddi kişilik problemleri ortaya çıkarmaktadır. Dolayısıyla bu sendrom da diğer psikolojik rahatsızlıklar gibi kurmaca kişilerin tasarlanmasında yazarın yaratıcı bilincini harekete geçirebilir. Böylece kurmaca kişiler, derinliği olan karakterlere dönüşebilirler.

\section{Trajediye tutkuyla bağlanmak}

Kurmaca dünyanın merkezinde yer alan insanın gerçek hayatta olduğu gibi kurmaca kaderinin de en çarpıcı tarafını trajediler ya da dramlar oluşturur. Tutunamayan bir kahraman, tutunabilmeyi başaran bir kahramandan çok daha cazip bir hikâyenin sahibidir. Kötü talihli insanların hikâyesini anlatmak da dinlemek de merak uyandırıcıdır. Belki de bu nedenle trajik bir hikâyesi olan kurmaca kişiler, okurun ilgi alanından hiç uzaklaşmaz, hafızalara kolayca yerleşirler. $\mathrm{Bu}$ durumu, psikolojide "schadenfreude/kötü niyetli sevinç" terimiyle karşılanan "başkasının acısından zevk almak" duygusuyla ilişkilendirmek doğru olmayacaktır. Zira başkasının acısından haz alma duygusunun altında patolojik bir sorun olabileceği gibi bunun olumsuz bir duygu olduğu ortadadır. Öte yandan diğer insanların yaşadığı acıyı, yazma eyleminin merkezine yerleştirmek ya da böyle bir hikâyeyi anlatan eseri okumak, hayatı anlama ve anlamlandırmaya katkı verebileceği gibi büyüme ve olgunlaşma vesilesi de olabilir. Okur, kurmaca kişinin dramından hareketle hayata ve insana dair yeni şeyler öğrenirken, kendi adına sorgulamalarda, keşiflerde bulunur.

Trajiğin, dram veya acının yazara ne ifade ettiği ya da yazarın neden trajik olana yönelme isteği duyduğu, her sanatkâr tarafından farklı cevaplanabilecek bir sorudur. "Okumayı ve yazmayı ruhu doyuran bir faaliyet olarak gören" (Harmancı, 2004: 66) Ayfer Tunç, bir hikâye yazarı olarak "insan ruhunun farkında olmadığımız halde bizi acıtan girift yanlarını kurcalamak için" yazdığını dile getirir ve "acı hikâyelerin iyi yazılmış bir edebiyat metni olarak okuduğunda duyulan acının edebî hazla donanmış”

\footnotetext{
RumeliDE Dil ve Edebiyat Araştırmalar Dergisi Osmanağa Mahallesi, Mürver Ciçeği Sokak, No:14/8 Kadıköy - İSTANBUL / TÜRKIYE 34714 e-posta: editor@rumelide.com tel: +90 505 7958124, +90 2167730616 
(İnci, 2014: 106) olduğuna işaret eder. Bu açıklama, yazarın trajediye tutkuyla bağlandığını göstermektedir. Trajedi ya da acıya tutkuyla bağlılık, yazarın kurmaca kişilerinin kurgusal benliklerini şekillendirir. Bu nedenle onun hikâyelerinde genellikle incinmiş ya da incitilmiş, mutsuz, yalnız kahramanların kederli hayatları okunur.4 İnci'nin dile getirdiği gibi "yazarın bütün hikâyeleri ölümle biter. Mutlu son, mutlu aşk ya da memnuniyetle yaşanmış tek bir aşk yoktur.” (İnci, 200o'den aktaran: Lekesiz, 2001: 412)

Umut yerine karamsarlıktan hareket eden Ayfer Tunç'un acıyı anlatma tercihi, tasarladığı kurmaca kişilerin kötü yazgılı olmalarına, trajik, dramatik ya da hazin hikâyeler içinde bir ömür tüketmelerine neden olur. Yazar, bir söyleşisinde acıyla ilgili düşüncelerini şöyle anlatır:

\begin{abstract}
“Acı bu metinleri yazmama neden olan şey, dünya acılı bir yer çünkü, hayat acılı bir süreç. Ama yaşayabilmek için acıyı inkâr etmek, baș etmeye çalışmak, kararlar vererek aşmak zorundayız. Bu baş etme ve aşmaya çalışma sürecine de hayat diyoruz. Hayat acının sürekli olması halidir. İnsanın hayatını boğan acılardan kurtulup mutluluğa erișmesi bir tür başarı öyküsüdür, nadirdir, aslolan acıdır. Bu tür başarı öykülerinin yeri okuru rahatsız eden ve sorgulayıp düşündüren edebiyat değil, okurun tatmin olmasını gözeten edebiyattır. Okurların çoğu edebiyattan bunu bekler. Karakterle özdeşleşir, kazanmasını, kötüleri cezalandırmasını, arzularına ulaşmasını ve kendi yoluna bir ışık tutmasını ister, böylece kitabı kapattığında rahat eder. Ben edebiyatın mutluluk reçetesi, okura yol gösterme kılavuzu olduğunu düşünen ve metinlerini bu amaca ulaşmak üzere kurgulayan bir yazar değilim. Edebiyat yaralarımızı gösterir, rahatsız eder, tedavi önermez. Yazarın yazdıklarından bir reçete çıkarmak istiyorsa okur çıkarabilir elbette, hatta çıkarmalıdır, başını kaldırıp çevresine bakmalı, kendini düşünmeli ve sorgulamalıdır. Sorgulama dediğimiz şey de somut soruları sormak ve kısa süre içinde cevaplarını bulmak ve bu cevaplara göre yola devam etmek değildir. Rahatsız olmak ve bu rahatsılılıla yaşamaya devam etmek bir tür sorgulamadır." (Hamamcı, 2017; "Ayfer Tunç ile Söyleşi”, http://www.sabitfikir.com/dosyalar/odakyazar-ayfer-tunc-ı, Erişim tarihi: 04.10.2021)
\end{abstract}

Görüldüğü gibi yazarın, trajik ya da dramatik hikâyeler anlatma isteğinin altında, acıyla kurduğu ilişki yatmaktadır. Acıyı hayatın merkezine alan Tunç, açıklamasında bir yandan neden acıya yönelmiş olduğunu, bir yandan da bu tercihin okur tarafından nasıl karşılandığına ya da karşılanması gerektiğine dair düşüncelerini ortaya koyar. Mutluluk reçeteleri yazmadığını dile getiren yazar, eseriyle okuru rahatsız ettiğini ifade ederek yazmanın görünür kıldığı, okumanın ise sorgulayıcı bir tarafı olduğu tespitini doğrular. Tunç'a göre okur, eserde anlatılan acıdan payına düşeni çıkarma konusunda özgürdür. Bu noktada yazarın, kötü yazgılı kahramanların hikâyelerini sadece anlatmakla yetinmediğini, onları karmaşık duygularıyla ortaya koymayı tercih eden yazarlardan biri olduğunu söylemek gerekir. Tunç, hikâyeyi anlatırken kurmaca kişilerin psikolojilerini anlamayı kolaylaştıracak olay, durum ve olguları da ortaya koyar. Dolayısıyla onun hikâyelerinde, okurun anlatılanlardan rahatsızlık duymasına, kendini sorgulamaya başlamasına neden olacak bir anlatım söz konusu olur. Duygular ve düşünceler yoluyla iç dünyası ifşa olan kurmaca kişiyle aynı oranda olmamakla birlikte, okur da acıya, kedere, hüzne ortak olabilir. Bu durum ister istemez karamsar bir bakış açısının

Ayfer Tunç'un hikâyeleri ve hikâye anlayıșı üzerine yapılan çoğu çalışmada bu durum dile getirilmiştir. Örneğin Handan İnci, Tunç’un hikâye kişilerini şöyle değerlendirir: "Ayfer Tunç, çağımızın çok uzağında duran, incelikli, gündelik olanla uzlaşamayan, tutunamamış, çoğu hayatı daha 'baştan kaybetmiş’ gölge insanları anlatıyor bize. Aramızda -ola kiyaşasalar bile göze çarpmayan, hemen fark edilmeyen, konuştukları dil, dinledikleri müzik, kullandıkları eşyalar, yaşadıkları evler ve semtlerle, artık var olmayan bir İstanbul'a ait gibiler. Belki de bu yüzden bu hikâyelerde yer yer karamsarlığa kayan yoğun bir hüzün var. Karşıllk bulmamış, değeri bilinmemiş aşkların, yalnızlı̆ın ve ölümün beslediği bu dünyaların kahramanları ise büyük çoğunlukla yaşlılar ve erkekler. 'Cinnet Bahçesi’ndeki Müyyet Bey'i, 'Gençlik Sabah Çiyidir'deki yaşlı adamı, 'Siz ve Şakalarınız’nn Samim Bey’ini, 'Alafranga İhtiyar'daki Ulvi Efendi'yi (Mağara Arkadaşları), Aziz Bey’i ve 'Soğuk Geçen Bir Kış’taki Semavi Bey’i (Aziz Bey Hadisesi) neredeyse tek bir kişide toplamak, onları, hayata karşı alınmış belirgin bir algılama biçiminin parçalanmış yansımaları olarak görmek de mümkün.” (İnci, 200o'den aktaran: Lekesiz, 2001: 412).

RumeliDE Dil ve Edebiyat Araştırmaları Dergisi Osmanağa Mahallesi, Mürver Ciceği Sokak, No:14/8 Kadıköy - İSTANBUL / TÜRKIYE 34714 e-posta: editor@rumelide.com tel: +90 $5057958124,+90216773$ o 616

\section{Address}

RumeliDE Journal of Language and Literature Studies

Osmanağa Mahallesi, Mürver Çiçeği Sokak, No:14/8

Kadıköy - ISTANBUL / TURKEY 34714

e-mail: editor@rumelide.com,

phone: +90 $5057958124,+902167730616$ 
egemenliğini gündeme getirir. Yazara bir söyleşide, karamsarlık bağlamında aşağıdaki soru yöneltilir ve Tunç’un bu soruya verdiği cevap, neden trajik olanı tercih ettiğini açıklar niteliktedir.

\begin{abstract}
"Öykülerinizde hayata yenilmiş insanlar geçmişteki acılarıyla, yalnızlıklarıyla, yenilgileriyle yüzleşiyor ve gelecek, bir umut vadetmiyor onlar için. Karamsar bir öykücü diyebilir miyiz bu açıdan Ayfer Tunç için?”

"Karamsardım, giderek ölesiye karamsar, ölesiye umutsuz oluyorum. Umuda hiçbir zaman tüm kalbimle inanmadım, kandırıcı bir tarafi olduğunu hissettim. Metinlerim nedeniyle duygusal hatta melankolik sanılsam da çok gerçekçi hatta gerçeğe aşıı bağlı bir yazarım. Gerçekle sağlam bağları olmayan bir umudun aptalca hayalperestlerin dayanağı, gerçeği gölgeleyen bir perde olduğu kanısı hep vardı bende, giderek güçlendi. Umut soyut ve boş bir kavramdır, içini doldurmak için eylem ister." (Bozkaya, 2017; "Ayfer Tunç ile Söyleşi”, http://www.sabitfikir.com/dosyalar/odakyazarayfer-tunc-11, Erişim tarihi: 04.10.2021)
\end{abstract}

Hikâyelerinde karamsarlığa, umutsuzluğa, santimantal bir hassasiyetle ve romantik bir duyarlılıkla değil; gerçekçi bir bakışla ulaşmış olması, yazarın hayatta öncelikle acıyı ya da acı olanı görmeyi tercih ettiğini gösterir.

Tunç, karamsar bir yazar olarak kırgın hayatların hikâyelerinin anlatıcısı olduğunu 1989'da yayımladığı ilk kitabı Sakl'dan5 itibaren göstermiştir. Türk hikâyeciliğinin gelişimine katkı ve yön veren hikâye yazarlarından biri olacağını haber veren Sakl’yı, Mağara Arkadaşları (1996), Aziz Bey Hadisesi (2000), Taş-Kâğıt-Makas (2003), Evvelotel (2006) adlı hikâye kitapları takip eder. Genel olarak hikâyeleri klasik kurgulu olay hikâyesi bağlamında değerlendirilse de yazarın, yer yer modern anlatım tekniklerinden yaralandığı da görülür. Lekesiz, Aziz Bey Hadisesi üzerinden bu durumu şöyle değerlendirir:

“Aziz Bey Hadisesi”ndeki öyküler, örgüsel olarak kulağı tersten gösteren ve anlaşılmak için okurdan çaba bekleyen hikâyeler olmamakla klâsik; bakış açısındaki kuşatıcıllk, söylemdeki dirilik, durumlar/olaylar arasındaki seri geçişlilikle modern anlatım biçimlerini içselleştirip, geleneksel anlatı biçimlerini bu iyi özümlenmiş anlayıştan/zevkten/süzgeçten geçirerek sunan bir öykücünün öyküleridir" (Lekesiz, 2001: 413).

Kendine özgü bir anlatım tarzı olan Ayfer Tunç, olay hikâyesinin sürükleyiciliği içine modern kısa öykünün anlatım biçimlerini ve bireyin iç dünyasını yerleştirir. Bu hikâyelerde zaman olabildiğince geniş tutulur ve çoğunlukla, kurmaca kişilerin bir ömürlük serüveni aktarılır. Bu nedenle bu tür kader hikâyeleri, kısa roman olarak da değerlendirilebilir.

\title{
2.1. Dramatik bir hikâye
}

Ayfer Tunç’un üçüncü öykü kitabı olarak yayımlanan Aziz Bey Hadisesỉnde ${ }^{6}$ genel olarak trajik hikâyeler anlatılmaktadır. Eserin ilk baskısında, kitaba adını veren hikâyenin dışında, "Kadın Hikâyeleri Yüzünden”, “Soğuk Geçen Bir Kış”, “Kar Yolcusu”, "Mikâil’in Kalbi Durdu”, “Kırmızı Azap” başlıklı beş

\footnotetext{
5 1964’te Adapazarı’nda doğan Ayfer Tunç, yükseköğrenimini İstanbul Üniversitesi Siyasal Bilgiler Fakültesi’nde tamamlar. Yazı yazmaya üniversite yıllarında başlayan Tunç’un edebiyat üzerine ilk yazıları 1983’ten itibaren ceșitli dergilerde yer alır. 'Saklı' adlı öyküsü 1989'da Cumhuriyet gazetesinin düzenlediği 'Yunus Nadi Öykü Armağanı’nı alır. 2001 yılında yayımlanan Bir Maniniz Yoksa Annemler Size Gelecek ile de 2003 yılında Uluslararası Balkanika Ödülü’nü kazanır. Çeşitli gazete ve dergilerde de çalıșan Ayfer Tunç’un yayımlanmış altı hikâye kitabı dıșında, Kapak Kızı (1992), Bir Deliler Evinin Yalan Yanlış Anlatılan Kısa Tarihi (2009), Yeşil Peri Gecesi (2010), Suzan Defter (2011), Dünya Ağrısı (2014), Âşıklar Delidir ya da Yazı Tura (2018), Osman (2020) adlı romanlarının yanı sıra çeşitli konularda yazılmış araştırma kitapları da bulunmaktadır. (Bk. Altundaş, 2020;http://www. teis.yesevi.edu.tr/madde-detay/ayfer-tunc, Erişim tarihi: 04.04.2021)

$6 \quad$ Bu çalıșmada esas alınan baskı; Aziz Bey Hadisesi, 1. Baskı, YKY, İstanbul 2000, 134 sayfa.

Adres $\mid$ Address

RumeliDE Dil ve Edebiyat Araşttrmalar Dergisi $\quad$ RumeliDE Journal of Language and Literature Studies Osmanağa Mahallesi, Mürver Çiçeği Sokak, No:14/8 Osmanağa Mahallesi, Mürver Çiçeği Sokak, No:14/8

Kadıköy - İSTANBUL / TÜRKIYE 34714 Kadıköy - ISTANBUL / TURKEY 34714 e-posta: editor@rumelide.com e-mail: editor@rumelide.com,

tel: +90 505 7958124, +90 2167730616 phone: +90 505 7958124, +90 2167730616
} 
hikâye daha yer alır.7 Okuyucu, “Aziz Bey Hadisesi”nde Tamburi Aziz Bey’in kederli hikâyesini okur. Tunç, bu hikâyeyi kahramanın macerasının tamamlandı̆̆ı yerde başlatır. Çalıştığı meyhaneden tartaklanarak dışarı atılan kurmaca kişinin gördüğü muameleye neden olan olay, daha sonra öğrenilecektir. Fakat anlatı dizgesini oluşturan dramatik aksiyonun başında, Aziz Bey’in bu acı olaydan kısa süre sonra ebedî saadete kavuştuğu haberi verilir. "Hadiseden birkaç saat sonra, evine giden Aziz Bey, gözlerinde biriken yaşlarla maziyi hatırlar ve hurma ağaçlarının, çok yüksek palmiyelerin gölgelediği sıcak ve alabildiğine mavi bir şehirde yaşadığı, çok kısa ama çok mutlu geçirdiği üç günü hatırlar. Yanılgılarla dolu bir ömrün bütün çilesini saklamaktan vazgeçtiği anda da hayata gözlerini yumar. Her şey olup bitmiştir artık." (s. 8) Acıya tutkuyla bağlı olan yazarın "incinmiş ruhlarından biri” (Harmancı, 2004: 65) olan Aziz Bey'in, ölmeden hemen önce mutlulukla hatırladığı, palmiyeler altında geçen üç gün, kaderini tayin eden olaya dair önemli bir ayrıntıdır. Dramatik yıkımlar içinde hayata tutunmaya çalışırken yaşanmış olan bu üç günden başka hatırlanabilecek başka güzel bir anı da yoktur. Zira yazar, kahramanını bu acı kaderi yaşayacak şekilde tasarlamıştır.

Aziz Bey; sevgisini göstermeyen, sert, kızgın bir babanın sorumsuz, uçarı oğlu olarak büyür. Burnu havada, havai, çapkın, yakışıklı bir genç olarak hayata atılır ve okuldaki başarısızlığını, sebatsızlığını, babasının yardımlarıyla girdiği işlerde de sürdürür. Ancak gerçek anlamda “dram Maryam’la başlar." (s. 13) Ailesiyle birlikte Beyrut'a giden Maryam'ın gönderdiği uzun şiirli mektuplar, aşkını unutmasına izin vermez. Aziz Bey, "bu cevabî mektuplarda aslolanın aşk değil, bırakılıp gidilenin haline duyulan doymak bilmez bir merak olduğunu göremez. Âşık olmayan bir göz, filmlerden, romanlardan edinilmiş bu basmakalıp satırları okusa, Maryam'ın da aşkın kendisinden değil, ardında bıraktığı yıkıntıdan haz alan kadınlardan olduğunu kolayca anlayabilir" (s. 19) ama o, anlayamaz ve mektuplardaki davete aldanarak Beyrut'a gider. Yalnızlık, yabancılık ve sıkıntıyla dolu bu maceradan hem acı bir tecrübenin sahibi hem de bir çalgıcı olarak döner. Kısa sürede Tamburi Aziz Bey olarak tanınan kahraman, dik başl, gururlu ama yalnız biri olarak hayatını sürdürür. İlerleyen yaşında, sessiz, sedasız bir hanım olan Vuslat'la evlenir. Vuslat'ın hastalığı sırasında, ne kadar bencilce yaşadığını, onu hiç görmediğini fark eden Aziz Bey, karısının ölümünden sonra da bu kez, onun yasını tutmayı bir tutku gibi sürdürür. Çalıştığı meyhaneden tartaklanarak kovulmasına neden olan bu yas hâli, ölümüyle nihayete erer.

\subsubsection{Aziz Bey'in trajik kusuru: Gurur}

Hikâyenin merkezinde yer alan Aziz Bey’in, dramatik yazgısına ve yaşadığı olumsuzluklara bir tür trajik hata gibi tanımlanabilecek olan aşırı kibir, gurur ve kendini beğenmişlik duygusunun neden oluğu söylenebilir. Yukarıda ifade edildiği gibi, mitlerden itibaren kahramanlarda görülen trajik hata, Aziz Bey'in kurmaca kişiliğinde de aşağılık kompleksiyle birleşir ve onun sorunlu kişilik yapısını oluşturur. Aşağgllk kompleksinin olduğu çoğu trajik benlikte görüldüğü gibi onun hayatında da "üstünlük sağlamak üzere" (Indick, 2011:214) ortaya koyduğu çaba, sorunlu bir benlik algısı oluşturmuştur. Bir diğer ifadeyle Aziz Bey'de de "[a]şırı aşağılık duyguları doğal olarak üstünlük yönünde aşırı tepkiler üretmiştir." (Indick, 2011:215) Aziz Bey'in kişiliğinde ortaya çıkan aşağılık duygusuna babasının davranışları neden olmuş olabilir. Kahramanın bu duyguyu dengeleme çabası ise “üstünlük kompleksi”ni doğurmuştur. Indick, "aşırı aşağılık duygularının doğal olarak üstünlük yönünde aşırı tepkiler ürettiğini ve bu aşırı tepkilere 'aşırı dengeleme' denildiğini, dengelemenin aşağılık kompleksi nevrozunu gidermenin normatif bir yolu olduğunu söyler. Aşırı dengeleme davranışlarının patolojik ve uyumsuz sonuçlar doğurduğunu dile getiren Indick, sürekli ve genel aşırı dengelemenin, bireyin etrafındaki insanlara

Ayfer Tunç, “Aziz Bey Hadisesi” tek basılsın istemiş ama kalan hikâyeler ayrı bir kitap oluşturmadığı için ilk baskıda eser bir öykü toplamı olarak çıkmıştır. Daha sonra yazarın bu isteği gerçekleşmiş ve eser bağımsız bir kitap olarak basılmıştır. (İnci, 2014: 67) 
hükmetme ve onları küçük düşürmeye yönelik patolojik bir gereksinimi dışa vurduğu bir kişilik bozukluğu olan 'üstünlük kompleksi’ne yol açabileceğini belirtir. (2011:216) Bu noktada, yazarın, kahramanın kişiliğini oluştururken diğer kişilerin rolüne müracaat ettiğini, bu nedenle diğer kişileri tasarlarken de değişik ölçülerde psikolojiden yararlandığı söylenebilir. Bu durum, sadece kurmaca kişileri belirlemeye yardımcı olmamış aynı zamanda dramatik aksiyondaki entrik yapıyı hazırlayacak olan karmaşık ilişkiler ağını da oluşturmuştur.

Sert ve anlayışsız bir babanın gölgesinde büyüyen Aziz Bey, okulda başarı gösteremediği gibi, babasının zoruyla girdiği işlerde de tutunamaz. "İki ufak penceresi kasvetli, kara kum yığınlarına bakan, ter, zift ve soğan kokan basık yazıhanede, başı yerde, omuzları düşük, 'Evet efendim, sepet efendim' diyerek çalışmaya başlayınca, hayatın ne çetin bir kavga olduğunu” (s. 13) anlar. Bu kasvetli ortam Aziz Bey’in "hülyalı başına vurmaya başladığı" (s. 13) sırada Maryam'dan da davet mektupları gelmektedir. Sonunda hem evdeki hem de işyerindeki tutsaklıktan kurtulmak için işten ayrılır. Hayırsız oğlunun işten ayrıldığı haberini alan babanın verdiği tepki, Aziz Bey’in nasıl bir babanın elinde büyüdüğünü ortaya koyması bakımından dikkate değerdir:

\begin{abstract}
“(...) Babası derin bir nefes aldı ve gittikçe öfkelenerek, öfkelendikçe sesi yırtılarak konuşmaya başladı. Dilinin kemiği yoktu, ağzına geleni söylüyordu. Hakaret dolu cümlelerle Aziz Bey’e bağırdıkça annesi fena oluyor; bir oğluna, bir kocasına dili tutulmuş gibi bakıyordu. (...) Aziz Bey'in ne adiliği, ne dilenciliği, ne sütünün bozukluğu kaldı. Küfre varan hakaret cümleleri odanın duvarlarında çınlıyor, Aziz Bey’in içinde çırpıldıkça köpüren yumurta akı gibi hafif, kendinin de şaşırdığı bir sevinç büyüyordu. Oğlunu baharat, çiçek ve limon kokularının birbirine karıştı̆̆ı, sıcak bir ülkeye çağıran mektuplardan haberdar olmayan baba, sonunda oğlunu evden kovdu. Ona batakhanelere, pis sokaklara, en adi orospuların yanına layık olduğu söyledi. "Karşımda daha fazla dikilerek bu temiz ve şerefli evi kirletme! Defol!..” dedi.” (s. 21)
\end{abstract}

Evden kovulan Aziz Bey, annesine veda etmek isterken babasıyla tekrar karşılaşır ve bir kez daha hakarete uğrar. Bunun üzerine "sokak kapısını öyle bir şiddetle vurup çıkar ki, önü lale motifli demirle süslü kapının camı şangırtıyla aşağıya iner. O sırada, annesi uğradığı felakete dayanamayarak yere yığılmıştır ama Aziz Bey ardında ne bıraktığını hiç aklına getirmeden, içinde sevgilisinin de bulunduğu yepyeni bir yurda tüm iştahı ve gücüyle gitmeye hazırdır." (s. 21) Bu iştahlı gidişin bedeli ağır olur. "Hayat, babasının istediğinden çok daha fazla burnunu sürter, ona hak etmediği kadar ağır bir ders verir. Peki, Aziz Bey bu dersi alır mı? Hayır...” (s.41) Evini, mahallesini, yaşadığı şehri terk ederek özgürlüğüne ve aşkına kavuşmak için gittiği Beyrut’ta yaşadığı sıkıntılara rağmen, döndükten sonra başı eskisinden de dik, burnu daha da havadadır. Hikâyede bu durum şöyle verilir:

"Aziz Bey de birçokları gibi hayatla inatlaşmayı, didişmeyi tercih etti. (...) O yaranın acısını bastırmakla, yaradılışındaki o dik başlı, hatta kibirli duruşu abartmakla, ona genç yaşında ağır bir darbe indiren hayata karşı küstah durmaya çalışmakla geçirdi bir ömrü.(...) Başı eskisinden de dik, burnu daha da havadaydı.” (s. 41-43)

Altı çizili cümlelerden de anlaşllacağı üzere, Aziz Bey yaşadı̆̆g dramatik yaralanmalara rağmen, öncekinden daha dik durmaya ve daha kibirli davranmaya çalışmaktadır. Bu kibirli dik duruş, hikâye boyunca sıklıkla dile getirilen trajik bir kusurdur. Adler’in, tespit ettiği gibi "aşağılık, güvensizlik ve yetersizlik duyguları", Aziz Bey için de "yaşamda bir amacın saptanmasını ve biçimlendirilmesini sağla[mış]" ve "saygınlığa kavuşma eğilim[leriyle] (2009: 96) şekillenmiştir. Buradan hareketle Aziz Bey'in kişiliğine bakıldığında, hayatta saygınlık kazanmak amacının kibirli, gururlu duruşla birlikte ilerlediği görülür. Yaşı ilerledikçe bu gururlu eda bakışlarına, duruşuna siner ve çevresindeki herkese yukarıdan bakar. "Yakışıklı bir adam olarak orta yaşa yaklaştığında haline tavrına bir olgunluk, bir güngörmüşlük gelir. Kendini hep ağırdan satan, iş teklifleri gelince acele etmeyen, ince eleyip sık dokuyan, kendi küçük piyasasında tanınan, saygı gören” (s. 46) bu adamın sadece kendini düşünen, 
kendi duygularıyla ilgilenen narsist bir tarafının olduğu da söylenebilir. Dolayısıyla babanın aşağılamalarına karşı geliştirilen üstünlük kompleksinin bir yansıması olan saygınlık kazanma arzusu, neredeyse kahramanın hayatını tamamen idare eden bir duyguya dönüşür. Bu durumda, trajik kusurun aşağllık kompleksini dengelemek adına aşırı bir üstünlüğe ve dolayısıyla üstünlük kompleksine dönüşmesindeki öncelik sonralık durumunu tespit etmek güçtür. Yukarıda ifade edildiği gibi trajik kusurla birleşen aşağılık kompleksi, kahramanın kişiliğinde daha karmaşı sorunları ve/veya sendromları ortaya çıkarmıştır.

\title{
2.1.2. Narsisizm ve Peter Pan sendromu
}

Gurur, Aziz Bey'de neden ve nasıl gelişmiştir? Bu duygunun oluşmasına yol açan ya da kahramanı böyle davranmaya iten nedenleri araştırmak, onu tanımaya yardımcı olabilir. Aziz Bey’in, yaşamında üzerine düşen sorumlulukları alma veya onlardan kaçma durumu, bencilliği, aşırı gururlu oluşu, yaşadığı olaylar karşısında doğru tepkiler verememesi "Peter Pan Sendromu" ile ilişkilendirilebilir. Dan Kiley, insan hayatında birçok probleme neden olan bu sendromu şöyle değerlendirmiştir:

\begin{abstract}
"Bu erkekler yirmilerinden önceki ve sonraki birkaç yll boyunca düşüncesiz bir yaşam tarzına dalarlar. Narsisizm onları kendi içine kilitlerken, gerçekçi olmayan bir ego tribi (kendini beğenmişlik) de, hayallerinin söylediği her şeyi yapabileceklerine ve yapmaları gerektiğine onları ikna eder. Gerçeğe uyum sağlamakta güçlük çektikleri yılların sonunda yaşam tersine dönmüş gibi görünür. "İstiyorum" un yerini "Yapmalıyı" alır. Kendilerini kabul ettirmelerinin tek yolu, diğer insanların onları kabul etmelerini sağlamaktır.” (1997: XVI)
\end{abstract}

Sendromu izah eden bu açıklama, Aziz Bey’in kişisel tarihinde de neredeyse aynen tekrar eder:

"Pazar sabahları bile tıraş olan, sokağa şapkasız adım atmayan, adliyede memur babası, oğlu okusun, hâkim, savcı falan olsun istedi ama, Aziz Bey’in aklı hep bir karış havadaydı. Karanlık yüzlü kitaplar, çatık kaşlı hocalar, camları yarıya kadar gri yağllboyayla boyanmış sınıflar ona sıkıntı verdi. Nerede havai, eğlenceli, gel-geç bir iş var, onun peşine düştü. Bacağını sakatlayıncaya kadar top sahalarında koştu durdu. Birkaç yaz üst üste Florya plajında cankurtaranlık etti, üstü açı arabalarla plaja gelen kızların beğeni dolu bakışlarından çok hoşlandı. Şoförlüğe merak sarınca, Bakırköy-Taksim hattında dolmuşta çalıştı. Kazandı̆̆ı üç-beş kuruşu da meyhanelerde, randevuevlerinde yedi. Babası ne yaptıysa okumadı, pes eden babası oldu." (s. 12)

Kurmaca kişinin yirmilerinden önceki ve sonraki birkaç yılını özetleyen bu alıntı da göstermektedir ki, "Peter Pan Sendromu”nda söz konusu edilen "düşüncesiz yaşam tarzı, kendini beğenmişlik (ego tribi), onu da hayallerinin söylediği her şeyi yapabileceğine ve yapması gerektiğine ikna etmiş gibidir. Aziz Bey de bu yıllarda gerçeğe uyum sağlamakta güçlük çeker ya da gerçeği algıladığı kadarıyla değerlendirir. Dolayısıyla onun hikâyesinde de sendromda söz konusu edilen "sorumsuzluk, sosyal uyumsuzluk, yalnızlık, narsisizm ve sosyal iktidarsızlık” (Kiley, 1997: 21-32) aşama aşama kendini gösterir.

Sorumsuzluğun ve kendini beğenmişliğin belirgin biçimde egemen olduğu yıllarda Aziz Bey, Maryam’a âşık olur ve bu aşk, Kiley’in (1997: 10) tespitindeki gibi onda da bir saplantı hâlini alır. Çünkü “Maryam'ın ailesi ekmek parası peşinden Beyrut'a gidince bu sıradan aşk sakız gibi uzayacak ve çürüyecek vakit bulamaz; küslükler, kıskançlıklar, kavgalar derken, sonuna kadar yaşa[nıp], her ikisinin de hanesine birer gençlik aşkı olarak yazıla[maz].” (s.15) Aziz Bey'in Maryam’ın mektuplarını yanlış anlaması ya da genç kızın mektupları yazmasına neden olan gerçeği görememesi, hayatında bir krizin doğmasına neden olur. Bu, kahraman açısından "trajik bir yanlış anlama" (Indick, 2011:117) ya da gerçeği görememe olarak ifade edilebilir. Maryam’ın sadece sevilmekten, aşkın kendisinden ya da romantizmden hoşlanmış olması, Aziz Bey’in trajik bir figüre dönüşmesine yol açar. Öte yandan kahramanın arkasında ne büyük bir acı bıraktığını görmeden, aşkı uğruna evi terk etmesi, hem

\footnotetext{
RumeliDE Dil ve Edebiyat Araşttrmalar Dergisi Osmană̆a Mahallesi, Mürver Ciçeği Sokak, No:14/8 Kadıköy - İSTANBUL / TÜRKIYE 34714 e-posta: editor@rumelide.com tel: +90 $5057958124,+902167730616$ 
sorumluluktan hem de otoriteyi temsil eden babadan kaçıştır. Bu durum, "Peter Pan" kurtulmasına imkân veren "Asla Asla Diyarı"na uçuşuna benzetilebilir. Kiley’in, "Peter Pan Sendromu" kurbanının eninde sonunda otoriteyi temsil eden erkek ile sorunları olur (1997: 65) tespiti, bu hikâyenin kahramanı için de geçerlidir.

Aziz Bey, Beyrut'ta yaşadığı sıkıntılı çile evresinin ardından yurduna döndüğünde de başka trajedilerle karşılaşır. Gidişiyle annesinin ölümüne neden olan hayırsız evlada, baba evinin kapısı bir daha açılmamak üzere kapanmıştır. Bütün dik başlılığına rağmen babasını görmek için defalarca o kapıya gitse de içeriye alınmaz. Oğlunu affetmeyen baba, bir süre sonra yalnızlık, kimsesizlik ve bakımsızlık içinde hayata gözlerini yumar. Aziz Bey, babasının ölümü karşısında kendisinin de onu affetmediğini düşünerek teselli olmaya çalışır. Ama onun, anne ve babasının ölümlerinde pay sahibi olduğu ortadadır. Kurmaca kişinin hayatını idare eden duygu, ebeveynlerinin acı ölümleri değil, "kör bir göz, felçli bir să kol, tekleyen bir kalp gibi, ona hep acı veren” (s. 13) Maryam'a duyduğu aşktır. Bu nedenle Beyrut'ta yaşadığı aldatılmışlık, yalnızlık ve yabancılık duygusuyla baş başa kaldı̆̆ süreç "kriz dönemi” (Kiley, 1997: 36) olarak tanımlanabilir. Beyrut'ta tambur çalarak geçinebilecek bir para kazanmaya başlamasının ardından, krizin onun için yönetilebilir bir hâl aldığı görülür. Ancak bu yabancı diyarda yaşadıklarının acısını bir ömür boyu çekecektir. Oysa yaşanma şansı olsaydı bu aşk sonunda bitecek, ardından "Aziz Bey aşk acısıyla meyhanelerde hadise çıkartacak, kırıp dökecek, bir zaman daha hovardalık yapacak, sonra zamanla durulacak ve annesinin bulacağı, kendine denk bir kızla evlenecekti." (s. 16) Süreç, kahraman açısından beklenildiği gibi gelişmediği için "can sıkıntısı veren ama daha başa çıkılabilir ölçüde bir düş kırıklığı vadeden bir evliliğe veya kariyere doğru” (Kiley, 1997:36) ilerlemez. Bu kriz, onu, "bir yandan yıllarca sürecek olan bir düş kırıklığı içine sürüklerken bir yanda da doyurucu bir evlilik yapabilmekten uzaklaştırır" (Kiley, 1997: 36). Hatta bir süreliğine tatmin edici gibi görünen çalgıcılığa bağlı kariyerinin de sonu hüsran olur.

Aziz Bey, tutunamadığı hayatın sorumluluklarından kaçar ve sendromu yaşayan erkeklerde görüldüğü gibi o da "sorumsuzluğunu en üst düzeye çıkarmak için bozucu alışkanlıklar edinir" (Kiley, 1997: 38). Okulda başarısız olması, girdiği işlerden hemen sıkılması, hatta bir tür özgürlük imkânı veren tambur çalmaya yönelmesi de bununla ilişkilendirilebilir. Tambur, kahramana hem saygınlık kazandırmış hem de sorumluluklarından uzaklaşmasını sağlamıştır. Çocukken her eline alışında annesinin "Aman evladım! Koy onu yerine, baban görmesin sakın..." (s. 11) uyarısıyla karşılaşan Aziz Bey’in, "gençliğinde tamburi olayım diye bir derdi olmasa da kader onu bu yola iter. Uzun ve gölgeli hikâyesinin bir yerinde tamburu eline yapışır, kalır.” (s. 10) Fakat beklediği saygınlığa da onun sayesinde kavuşmuş olur. Önceleri sıkıcı işlerden kaçmak için canı ne zaman isterse, nerede isterse çaldığı tambur, bir süre sonra saygıyla anılmasını sağlar:

\begin{abstract}
"Hep burnu havada, hep bakışları ufukta kimselerin görmediği yüce bir noktada, çalımla yürür, sanatını dinlemek için sabırla bekleyenlere, epeyce ağırdan aldıktan sonra tamburunu lütfederdi. İzmir Fuarı sırasında organizatörler kapısında kuyruk olurlardı. En büyükleri değilse bile, onların bir altı sanatçılar arkalarında çalması için Aziz Bey’i bizzat telefonla ararlar, bu da yetmezse ricacılar koyarlardı araya. Hepsini kapısında süründürürdü. Çalışında bir ruh vardı, acayip bir şeydi onun tambura vuruşu. Şurup gibi gelirdi dinleyenlere. Aksiydi de oldum olası. Ama öyle etkileyici bir hali tavrı, öylesine ‘bu işleri ben bilirim’ diyen bakışları vardı ki, o gözkapakları mavi boyalı, sarı saçları kabarık, payetler, tüller, tüyler içinde kırıtan, kaprisinden geçilmeyen şarkıcılar, Aziz Bey’in karşısında dillerini yutarlardı.” (s.10)
\end{abstract}

Baba ile anlaşamayınca doyuma ulaşmak için mükemmelliği hedefleyen "Peter Pan Sendromu" kurbanları gibi, (Kiley, 1997: 109) o da tamburda mükemmelliği hedeflemiş ve başarmıştır. Bu durum bir anlamda sendrom kurbanları için söz konusu edilen "yapmalıyım" motivasyonuyla ilişkilidir. Aziz

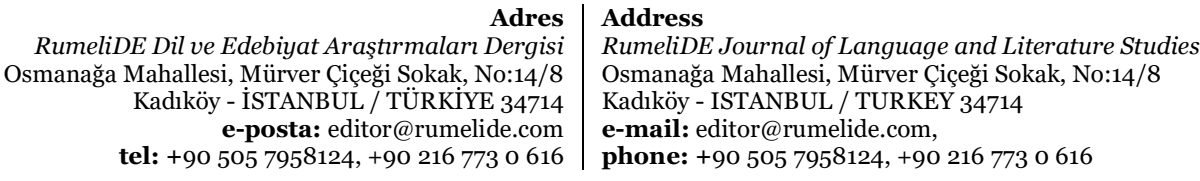


Bey, tambur çalarak hayatını kazanmaya karar verdikten sonra, arzu ettiği "mükemmellik" ve "saygınlık" da gerçekleşmiş olur. Kahramanın tamburda ustalaşma süreci, hikâyede belirsiz bırakılsa da sahip olduğu şöhretin gölgelendiği, itibarının tehlikeye girdiği bazı gelişmelerle yüzleşmek zorunda kaldığı durumlar, ayrıntılı olarak gösterilir. Zirve yılları bitip de eskisi gibi rağbet göremediği dönemlerde saygınlığı da örselenir. Bu yıllarda önce bir süre direnir ama sonra saygınlığına yakışmayan yerlerde de çalışmak zorunda kalır. Dünyanın değiştiği gerçeğini değiştirememiş, Kiley’in dile getirdiği gibi "mükemmelliğinin üstünlüğü tehdit altında" kalmıştır. İşte böyle zamanlarda "Peter Pan Sendromu" kurbanlarında görüldüğü gibi Aziz Bey’in de "tatlı mizacı yerini öfkeye bırakır" (Kiley, 1997: 109). Önceleri "bu yeni duruma, çok yakında geçeceğini, yeniden o renkli hayatına döneceğini umarak katlanmış, fakat katlanmak Aziz Bey’i daha da tahammülsüz, sinirli hatta saldırgan bir adam yapmıştır.” (s. 52) Bu dönemde Zeki'nin meyhanesinde bulduğu iş sayesinde yeniden hak ettiğini düşündüğü saygınlığa kavuşur ancak kahramanın "sorunlu benlik algısı" felaketini de hazırlar. Herkese yukardan bakan kibirli ve narsist tavırları gerçeği görmesini engeller. Denilebilir ki, "Peter Pan Sendromu”nda söz konusu edildiği gibi Aziz Bey de "gerçeğin çevresinden dolaşarak tekrar kendini en rahat hissettiği, mükemmellik görüntüleriyle çevrili yere” (Kiley, 1997: 109) doğru yönlenmiş, ama her şeyin kendi istediği gibi olmasında direten bencil ve gururlu tavrı, mahvına neden olmuştur. Oysa Aziz Bey, Zeki'nin teklifi ile âdeta hayata dönmüştür. Burada "çok mutludur. Yıllardır alıştı̆̆ için hakkı olduğuna tüm kalbiyle inandığı saygınlığa yeniden kavuşmuştur.” (s. 54) Yani yeniden kendini en rahat hissettiği mükemmellik içindedir. Fakat burada gördüğü değer uzun sürmez. Karısı Vuslat'ın ölümünden sonra yine kendisini merkeze koyar. Yaşadığı ölüm acısını her şeyin üstünde tutarak, bir tutku gibi bu yasa bağlanır. Eğlenmeye gelen müşterilere, kederli şarkılar söylemekte ısrar eder. Meyhane sahibinin ricalarına kayıtsız kalarak, yasını herkese yaşatmaya kararlı gibi davranır. Gerçeklik algısının iyice bozulduğu, narsisizmin doruğa çıktı bu süreç, Aziz Bey'in sonunu da getirir. "Kendini, her değdiği yeri yakan ateşten bir top sanan; içinde taze kalan bu efkârlı halin hep karşlık bulmasını bekleyen Aziz Bey, müşterilerin isteklerine hiç aldırış etmez, onları parasıyla eğlenmeye gelmiş insanlar olarak değil, kederinin gönüllü şahitleri gibi görür. Neşeli şarkılar istemeyi kendisine yapılan büyük bir saygısızlık sayar.” (s. 62-63) Bir süre yasına ve yaşına hürmeten idare edilen bu durum, giderek çekilmez bir hâl alır. Bu arada geçirdiği hastalık nedeniyle iyiden iyiye zayıflamış, çökmüş, eski görkemli halinden eser kalmamıştır. Ama Aziz Bey, bu gerçeği de idrak edecek durumda değildir. Aynı vakur, dik duruşunu muhafaza eder. Bir gece, neşeli bir şarkı isteyen müşterinin üzerine yürümesi de sonunu getirir. Tamburi Aziz Bey'e asla yapılamayacak olan yapılır. Kolundan tutulup dışarı atılır. Kahramanın gördüğü muamele acıtıcı olsa da "göstermeye çalıştığı kadar mükemmel olmadığ gerçeğiyle yüzleşmesine" (Kiley, 1997: 111) yol açar.

Natüralistlerin kişilik gelişiminde ve kurguda yer verdikleri kalıtım, yani genetik miras, bir kurmaca kişi olan Aziz Bey'in hayatında ve kişiliğinde de tevarüs eder. Emile Zola'nın, Claude Bernard'ın Introduction à la Médecine Expérimentale / Deneysel Tıbba Giriş (1865) adlı eserindeki bilgileri kurmaca dünyaya aktarması ve insana bu bilimsel verilerden hareketle bakmasının ardından, natüralist yazarlar, "insanı kimyasal bir etki-tepki maddesi, biyolojik kalıtımın ve sosyo-ekonomik çevrenin bir mahsulü olarak görmüş[lerdir]” (Kantarcıoğlu, 2007: 156). Bu bağlamda denilebilir ki Aziz Bey’in kurmaca bir kişi olarak kurmaca kaderi, fiziksel özellikleri ile kişiliği belirlenirken, natüralist eserlerde görüldüğü üzere, "insan hayatında gizli hiçbir şeyin olmadığı, insan hayatının sebep netice ilişkisi içinde tekrar eden olaylardan ibaret olduğu” (Kantarcıŏlu, 2007:156) tezinden hareket edilmiştir.

Dramatik aksiyonu oluşturan olaylar dizisinin başında yazar anlatıcı, "Aziz Bey'in dedesi ile babasının karışımı, hem ince ruhlu duygulu hem de dediğim dedik dik başlı bir adam olduğunu” (s. 12) söyleyerek kahramanın var edilmesindeki soyaçekime işaret eder. Bu varoluş/ediliş biçiminin kahramanın

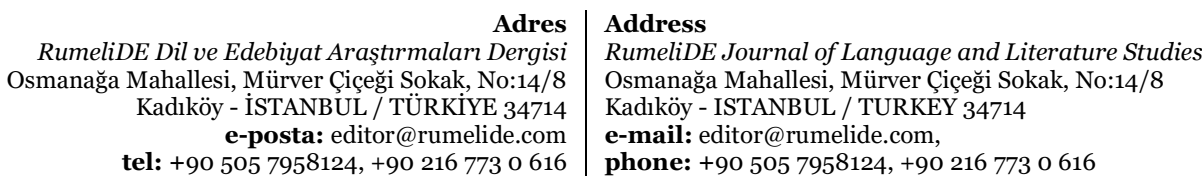


dramında büyük pay sahibi olduğu ortadadır. "İki mağrur cambaz aynı ip üzerinde yürümeye kalktığından, hep kavgahıdır babasıyla." (s. 12) Dan Kiley, "baba takınağı" yaşayan "Peter Pan Sendromu" kurbanının babasına yakın olmaya özlem duyduğuna ama onun onayını hiç alamayacağından da emin olduğuna işaret etmektedir (1997:9). Bu durum Aziz Bey’in yaşamında da görülür. O da babasına yaklaşmaya, onun onayını almaya çalışır. Beyrut'tan döndükten sonra "Peter Pan Sendromu kurbanları gibi babasını memnun edemediği için affedilmeyi umar.” (Kiley, 1997: 65) Affa mazhar olamadan babasını kaybedince de onun takım elbisesini giyerek sahneye çıkar. Füme rengi takım elbisenin, hem baba ve dede ile bir olmaya imkân veren genetik bağı hem de babaya rağmen elde edilen yeni kimliği simgelediği söylenebilir. Aziz Bey, babasının ölümünün ardından, ondan kalan füme rengi takım elbiseyi, kolalı gömleği giyer, kravatı takar ve programına biraz da babası olarak başlar. (s. 46) Bu durum "babasıyla sembolik bir yakınlı" (Kiley, 1997: 65) kurmasını sağlar. Babadan kalan takım elbiseyi giydikçe onunla barışıp suçunu paylaştığını (s. 46) düşür. Ancak kurmaca kişinin, gençliğinde çatıştı̆̆ı, suçladığı babasına ne kadar da benzediğini fark etmesi zaman alır:

"Kalkmak için koltuğun kollarını kavramıș elleri gözüne ilişti. Kendi elleri... Bu eller tıpkı babasının elleriydi. Ansızın, evlilikleri boyunca bu evin odalarında, memnuniyetsiz bir ifade ile dolaşan adamın kendisi değil, babası olduğunu fark etti, dehşete kapıldı.

Hiç farkına varmadan babası olmuştu. Kalbini karısına açmayan, evinin dışındaki hayatı evinin içindekinden daha önemli bulan, evdeki yürek sızılarını anlamayan, anlasa da umursamayan, çehresi daima asık, sesi daima gür ve azarlamaya hazır babası.

Konsolun aynasında yüzünü gördü. Aynı açık alın, sert hatlar, keskin bakışlar. Elini saçlarına götürdü, kolunun hareketinden aynaya yansıyan yine babasıydı. Geriye doğru taranmış, gümüșsü saçlarına dokunan parmaklar da onundu. Bir zamanlar yüzüne kapıyı çarpıp terk ettiği adam içine girmiş, orada sessizce ve yıllarca yaşamıştı.” (s. 53)

Yukardaki alıntıda görüleceği üzere Aziz Bey, hem fiziksel özelliklerini hem de mizacını babasından genetik bir miras olarak devralmıştır. Bu fark ediş, trajik kahramanın yaşamındaki önemli kırılma anlarından biridir. Aziz Bey'in babasına olan benzerliği, sadece soya çekim yasasıyla ve "insan hayatının sebep netice ilişkisi içinde tekrar eden olaylardan ibaret olduğu” (Kantarcığlu, 2007: 156) teziyle açıklanamayacak kadar karmaşıktır. Bu durum, hem trajik hata hem buna bağlı olarak gelişen aşağılık ve üstünlük kompleksleri hem de "Peter Pan Sendromu"yla ilişkilidir. Bir sorun diğerini doğurmuş ve sonunda sorunlu benlik algısı olan bir karakter doğmuştur.

Kiley, "sendromda iki aracı belirti saydığı narsisizm ve şovenizmden söz ederek; narsisizmin genellikle şovenizmden önce gelerek kurbana güvensizliğini diğer insanlara yansıtmak için sistemli bir yöntem sağladığını ve onu kendi fantezileri içine kilitleyerek, diğer insanlarla anlamlı ilişkiler kurmasıyla gerçekleşecek olan kişisel büyümeyi engellediğini belirtir. Şovenizmin ise, narsisist kurbana akranlarından sı̆̆ da olsa, kabul görmesini vaat eden bir 'yetişkin rolü' vererek kurbanı kalp acısına ve düş kırıklığına karşı korur." (1997: 27) Kiley’in "Peter Pan Sendromu" kurbanları için belirlediği bu iki belirtinin Aziz Bey’in kişiliğinde var olduğunu iddia etmek yanlış olmayacaktır. Aziz Bey, evlendiği kadınla anlamlı bir ilişki kuramamıştır. Benzer bir durum hayatı boyunca kurduğu diğer ilişkilerde de tekrar etmiştir. Öte yandan bu evliliğin ona bir 'yetişkin rolü' verdiği, hatta kalp acısına ve düş kırıklığına karşı onu koruduğu da ortadadır. Çünkü Aziz Bey’in, Vuslat'ı kendisine eş olarak seçmesinin iki nedeni vardır. Bunlardan biri Aziz Bey’in bencilliğinin doğurduğu kolaycılı̆̆ıdır:

“Âşık olacak, kapris çekecek, ortak hayatlarını bitmeyen istekler manzumesine çevirecek bir kadının gönlünü eyleyecek hali de, arzusu da yoktu. Öylesine bencil düşünceler içindeydi ki, ancak Vuslat gibi sessiz, silik, dikkatle bakılmadıkça görülmeyen, varlığına ihtiyaç duyulmadıkça ortaya çıkmayan; o konuşursa dinleyen, sorarsa cevap veren; kısacası hayatını alabildiğine kolaylaştıracak bir kadınla yaşayabileceğini düşünüyor, dahası böyle bir kadın istiyordu.” (s. 49)

\section{Adres $\mid$ Address}

RumeliDE Dil ve Edebiyat Araşttrmalar Dergisi $\quad$ RumeliDE Journal of Language and Literature Studies Osmanağa Mahallesi, Mürver Çiçeği Sokak, No:14/8 Osmanağa Mahallesi, Mürver Çiçeği Sokak, No:14/8 Kadiköy - ISTANBUL/TÜRKIYE 34714 e-posta: editor@rumelide.com tel: +90 $5057958124,+902167730616$

Kadıköy - ISTANBUL / TURKEY 34714

e-mail: editor@rumelide.com,

phone: +90 $5057958124,+902167730616$ 
Kahraman, evlenmek için sessiz, sedasız, silik bir kadın seçerek hem kendisini olası bir kalp kırıklığından, acısından korumuş hem de hayatını kolaylaştıracak gönüllü bir yardımcı edinmiştir. Bu tavır, bir yandan duygularını tatmin etmiş, diğer yandan da büyük bir aşk ve tutkuyla seven değil sevilen olarak ilişkideki üstünlüğü kazanmasını sağlamıştır. Bu da Vuslat'ın eş olarak seçilmesinin ikinci nedenidir. ${ }^{8}$ Vuslat, kocasına duyduğu aşkla onun gurunu okşamış ama hastalanıncaya kadar ondan ilgi ve sevgi görememiştir. Bu tek taraflı sevgi ilişkisinde Aziz Bey’in sendromun kurbanları gibi "mükemmelliğin güvenliği uğruna sevgiyi feda ettiği” (Kiley, 1997: 109) söylenebilir.

Aziz Bey'in kederli hayatını büyük ölçüde babanın kederli hayatı belirlemiştir. Yazar, bu tür sorunlu ilişkileri Haneke'den alıntıladığı "Ebeveynlerin günahları çocuklarının nevrozlarıdır" tespitiyle açıklar. Tunç'a göre yaralı anne babalar isteyerek olmasa da çocuklarını yaralarlar. (İnci, 2014: 52 ) Bu tespit "Aziz Bey Hadisesi” için de geçerlidir. Babanın oğlunu yaralaması, onda sendrom kurbanları gibi "baba takınă̆ı" ortaya çıkarmış ve kahraman hayatı boyunca bu sorunu aşamamış, aşmak için geliştirdiği çözümler de çare olmamıştır. Çocuk ile babanın ilişkisindeki sorun, kahraman adına kederli bir kader yaratırken, kurmaca kişi bencil, kibirli, dik başlı kişiliğiyle aslında hiç büyümeyen bir çocuk olarak kalmıştır. Kendi gerçeğini görüp, onunla yüzleştiğinde ise çok geç olmuş, hayat sona ermiştir.

\section{Sonuç}

Psikoloji biliminin verileri kurmaca dünyanın kurmaca kişilerini ve onlar için belirlenen kurmaca kaderleri şekillendirmektedir. Yazarın yaratıcı bilinciyle birleşen her bir bilgi ya da veri, hem kurmaca kimliklerin derinlik kazanmasına hem de kurmaca dünyanın şekillenmesine hizmet eder. Trajik, dramatik ya da acı bir hikâye oluşturmada etkili oldukları görülen "trajik hata" ve "aşağılık kompleksi", kahraman adına sorunlu, uyumsuz ve mutsuz bir kişilik oluşturduğu gibi, anlatı örgüsünü de şekillendirir. Yazarın acıyla kurduğu ilişkinin boyutlarına bağlı olarak anlatıda kendine yer bulan trajedi, dram ya da acının oluşmasında, kurmaca kişiye giydirilen kimliğin psikolojik tarafı büyük rol oynar. Trajedinin esas alındığı çoğu anlatıda kahramanın sorunlu kişiliği, psikolojik rahatsızlıkları kaderini de belirler. Böyle bir anlatı örgüsüne sahip olan “Aziz Bey Hadisesi”nde acılar, kırgınlıklar ve mutsuzluklarla örülü bir hayat anlatılmıştır. Trajik bir ömrü içine alan kurguda olaylar, kahramanın iç dünyasını anlamaya, psikolojisini ve hayata bakışını belirleyen temel kıılma noktalarını görmeye imkân verecek yönde düzenlenmiş ve bir araya getirilmiştir. Dolayısıyla bir yandan kurmaca kişinin yaşadığı sıkıntılar, sevgisizlik, doğru kurulamayan benlik algısı ve bunun ortaya çıkardığı trajik durum okunurken, diğer yandan da buna neden olan olay, durum ve olgular görülür.

Ayfer Tunç’un çoğu hikâyesinde olduğu gibi “Aziz Bey Hadisesi”nde de kahraman üzerinden, mikro düzeyde insanın bir temsili sunulmaktadır. Sorunlu, sakat ve marazî tarafın ağır bastığı bu mikro örnek, insana ve hayata dair çok şey anlatır. Sevgi arayışının getirdiği saplantılı aşk, bu aşkın neden olduğu kendi içine çekilme ve doğru kurulamayan ilişkilerle süren narsisist varoluş biçimi, evrensele ulaşabilecek çıarımlar sunar. Hikâyede aile, kurmaca kişiye yeterli düzeyde büyüme ve olgunlaşma imkânı veren bir ortam sunmadığı için, kahraman dünyaya açıldığında sağlıklı bir birey olarak tutunabilmeyi başaramaz. Yaşamaktan çok, maruz kalmak ve maruz kalınan duruma göre tavır takınmak, hikâye kahramanı açısından dramatik sonuçlar doğurur. Her şeyin bitmeye yaklaştığı anda fark edilen "yanılgılarla dolu bir ömür” geçirmiş olmak, hikâye kahramanı adına bir şey fark ettirmese

Şenol Topçu, “198o Sonrası Türk Öyküsünde Erkek ve Erkeklik Olgusu” başlıklı yüksek lisans tezinde "Aziz Bey”i evlilik kararına götüren şeyin narsist erkek yapısı” olduğunu belirterek meseleyi hegemonik erkek algısı yönünden değerlendirmiș ve Aziz Bey’in Vuslat’ı seçmesindeki narsisist tutuma dikkat çekilmiștir (2012:130).

Adres $\mid$ Address

RumeliDE Dil ve Edebiyat Araşttrmaları Dergisi Osmanağa Mahallesi, Mürver Çiçeği Sokak, No:14/8

Kadıköy - İSTANBUL / TÜRKIYE 34714 e-posta: editor@rumelide.com

RumeliDE Journal of Language and Literature Studies

Osmanağa Mahallesi, Mürver Çiçeği Sokak, No:14/8

Kadıköy - ISTANBUL / TURKEY 34714

tel: +90 $5057958124,+90216773$ o 616 phone: +90 505 7958124, +90 216773 o 616 
de okura çok şey anlatacak güçtedir. Çünkü trajik kahramanın kurmaca tecrübelerine yapılan tanıklık, acı hikâye üzerinden okunan hayat, insanı ve hayatı anlamaya dönüktür.

\section{Kaynaklar}

Adler, A. (2009). İnsanı Tanıma Sanatı, (çev. Kâmuran Şipal), İstanbul: Say.

Aristoteles (1987). Poetika, (çev. İsmail Tunalı), İstanbul: Remzi.

Harmancl, A. (2004). “Ayfer Tunç’la Öykü Serüveni Üzerine”, Hece, 87, 65-74.

Indick, W. (2011). Senaryo Yazarları İçin Psikoloji. (çev. Ertan Yllmaz-Yeliz Karaarslan), İstanbul: Agora Kitaplığı.

İnci, H. (2014). Ayfer Tunç’la Karanlıkta Kelimeler, İstanbul: Can.

Kantarcığlu, S. (2007). Türk ve Dünya Romanlarında Modernizm, İstanbul: Paradigma.

Kıran (Eziler), A.- Kıran, Z. (2003). Yazınsal Okuma Süreçleri, Ankara: Seçkin.

Kiley, D. (1997). Peter Pan Sendromu: Hiç Büyümeyen Erkekler, (çev. Semra Kunt), Ankara: HYB.

Lekesiz, Ö. (2001). Yeni Türk Edebiyatnda Öykü, C.5., İstanbul: Kaknüs, 405-439.

Nutku, Ö. (1990). Dram Sanatı (Tiyatroya Giriş), İstanbul: Kabalcı.

Stevick, P. (2004). Roman Teorisi, (çev. Sevim Kantarcıŏ̆lu), Ankara: Akçağ.

Şener, S. (2006). “Antik Yunanda Tiyatro Düşüncesi”, Dünden Bugüne Tiyatro Düşüncesi, Ankara: Dost., 15-53.

Topçu, Ş. (2012). 198o Sonrası Türk Öyküsünde Erkek ve Erkeklik Olgusu, (Basılmamış Yüksek Lisans Tezi), Çanakkale Onsekiz Mart Üniversitesi Sosyal Bilimler Enstitüsü Türk Dili ve Edebiyatı Anabilim Dalı.

Tunç, A. (2000). “Aziz Bey Hadisesi”, Aziz Bey Hadisesi, 1. Baskı, İstanbul: YKY., s. 7-73.

Wellek, R. - Warren, A. (1993). Edebiyat Teorisi, (çev. Ömer Faruk Huyugüzel), İzmir: Akademi.

\section{Internet kaynakları}

Altundaş, C. (2020). “Ayfer Tunç”, Türk Edebiyatı İsimler Sözlüğü, http://www. teis.yesevi.edu.tr/madde-detay/ayfer-tunc, Erişim tarihi: 04.04.2021

Bozkaya, İ. (2017). “Ayfer Tunç ile Söyleşi”, http://www.sabitfikir.com/dosyalar/odakyazar-ayfer-tunc11, Erişim tarihi: 04.10.2021

Hamamcı, E. (2017). “Ayfer Tunç ile Söyleşi”, http://www.sabitfikir.com/dosyalar/odakyazar-ayfertunc-1l, Erişim tarihi: 04.10.2021 